\title{
Women's Access to Managerial Positions: An Experimental Study of Leadership Styles and Gender
}

\author{
Isabel Cuadrado, J. Francisco Morales, and Patricia Recio \\ Universidad Nacional de Educación a Distancia
}

\begin{abstract}
This study attempts to test one of the explanations of the scarce representation of women in managerial positions, specifically the one advanced by "role congruity theory of prejudice toward female leaders" (Eagly \& Karau, 2002), which appeals to the fact that women get unfavorable evaluations if they adopt male-stereotypical leadership styles. One-hundred and thirty-six undergraduate students participated in an experiment with a 2 (Malestereotypical vs. Female-stereotypical leadership style) $\times 2$ (Male vs. Female leader) design. Dependent variables were leader's competence, efficacy, and evaluation in a series of traits. It was found that, regardless of sex, the leaders were considered more competent and efficient, and were evaluated more favorably, when they adopted stereotypically feminine leadership styles. Implications of these findings for women's underrepresentation as leaders in management top positions worldwide are discussed. Keywords: glass ceiling, leadership styles, gender, female leaders
\end{abstract}

\begin{abstract}
El objetivo de este estudio es investigar si, como postula la teoría del prejuicio de rol hacia líderes femeninos (Eagly y Karau, 2002), una de las causas de la escasa presencia femenina en puestos directivos es la devaluación de las mujeres líderes cuando adoptan formas de liderazgo estereotípicamente masculinas. Para ello, diseñamos un experimento en el que participaron 136 estudiantes. Se elaboró una historia en la que se manipulaba el estilo de liderazgo (estereotípicamente masculino vs. estereotípicamente femenino) y el sexo del líder (hombre vs. mujer). Las variables dependientes fueron la capacidad de liderazgo, la eficacia en el desempeño del liderazgo y la evaluación positiva o negativa del líder (medida a través de una lista de adjetivos). Los resultados indican que, independientemente del sexo, los líderes son mejor evaluados en todas las variables cuando ejercen el liderazgo con estilos estereotípicamente femeninos. Se discuten estos resultados a partir de la literatura psicosocial relacionada con el acceso limitado de las mujeres a puestos directivos.
\end{abstract}

Palabras clave: techo de cristal, estilos de liderazgo, género, mujeres líderes

This investigation was funded by the Vice-Rectory of Research of the Universidad Nacional de Educación a Distancia (UNED) as part of its plan for promoting research.

The authors wish to thank the three anonymous reviewers for their comments on prior versions of this article.

Correspondence concerning this article should be addressed to Isabel Cuadrado Guirado. Dpto. de Psicología Social y de las Organizaciones. Facultad de Psicología. UNED. C/ Juan del Rosal, 10. 28040. Madrid. E-mail: icuadrado@psi.uned.es

Translation: Virginia Navascués Howard. 
The relation between leadership styles and gender has recently become an important topic of research (i.e., Barberá \& Ramos, 2004; Cuadrado, 2003; Cuadrado \& Molero, 2002; Eagly \& Johnson, 1990; Eagly \& Johannesen-Schmidt, 2001; Eagly, Johannesen-Schmidt, \& van Engen, 2003; van Engen \& Willemsen, 2004), generating interesting debates in the literature, both in Spain (see Ayestarán, 2003; Cuadrado, 2003; Moya, 2003; Munduate, 2003), and beyond our frontiers (see Eagly \& Carli, 2003a, 2003b; Vecchio, 2002, 2003). As noted by Eagly and Carli (2003b), these studies are sometimes carried out to investigate whether the scarcity of women in managerial positions can be explained on the basis of the fact that they use less effective leadership styles than men, and sometimes, to investigate whether women use "superior" leadership styles than men's styles, which has recently been called the female leadership advantage (see Eagly \& Carli, 2003a, 2003b; Helgesen, 1990; Vecchio, 2002, 2003).

As seen in the pertinent literature (see, for example, Cuadrado, 2001; Eagly \& Johnson, 1990), the main styles on which classic research has focused are autocratic versus democratic and task-oriented/relationship-oriented. Autocratic leadership is characterized by the leader's making decisions unilaterally, not allowing the group members to participate. Democratic leadership is participative, consultative, and involves the group, and the leader allows and encourages group members' participation in the decisions (Cuadrado). Leaders who use a task-oriented style are mainly concerned with achieving the group goals - emphasis on achieving the task-whereas relationship-oriented leaders are basically concerned with their followers' wellbeing and satisfactionemphasizing the quality of relations with others-(Cuadrado). As indicated by Eagly and Johnson when referring to these styles (p. 236), "leadership research provides an excellent opportunity to determine whether the behavior of leaders is gender stereotypic." Men are generally considered more autocratic and task-oriented because of their relationship with the components of the "instrumental" dimension of gender stereotypes (e.g., aggressive, enterprising, independent, self-sufficient, dominant, competent, rational). In contrast, women tend to be considered more democratic and relationship-oriented, because the "communal" dimension is characterized by aspects such as being concerned with others, being generous, sensitive, understanding, affectionate, or compassionate (see Cuadrado, Navas, \& Molero, 2006). Studies carried out by Cann and Siegfried (1990) offer empirical support to this relation between gender stereotypes and leadership styles.

In the last decades, attention has focused on gender differences in "transactional" and "transformational" leadership (e.g., Cuadrado \& Molero, 2002; Eagly et al., 2003). Transactional leadership is characterized by the establishment of a kind of "exchange" between the leader and the group members. Transformational leaders do not limit themselves to establishing a mere exchange of rewards with their followers or subordinates, but instead they produce changes in their followers' scale of values, attitudes, and beliefs, thus getting them to attain much higher levels of achievement than expected and, therefore, higher levels of job satisfaction (Bass \& Avolio, 1990). As noted by Eagly and Johannesen-Schmidt (2001), although these styles are not so obviously related to gender as the former ones, transformational leadership has "communal" aspects, especially the factor "individualized consideration," which make it a style more aligned with women. Individualized consideration refers to the leader's capacity to pay personal attention to all the team members, making them feel that their individual contribution is important (Bass \& Avolio, 1990). Likewise, according to van Engen, van der Leeden, and Willemsen (2001), transformational leadership can be considered a "female" style, because of the emphasis on individualized consideration to subordinates (which is related to characteristics stereotypically attributed to women). These authors add that "many authors explicitly refer to this style as a female leadership style" (p. 583).

Therefore, in view of the above, the autocratic and taskoriented leadership styles are stereotypically male, whereas the democratic and relationship-oriented styles, with individualized consideration of team members are considered stereotypically female (see Cuadrado, 2003; Cuadrado et al., 2006).

The results from two meta-analyses carried out by Eagly and collaborators on gender and evaluation of leaders (Eagly, Makhijani, \& Klonsky, 1992), and on gender and effectiveness of leaders (Eagly, Karau, \& Makhijani, 1995) have important implications for the consequences of each sex of adopting male or female leadership styles. Thus, the first of these meta-analyses showed that female leaders obtained poorer evaluations than males when they adopted a male-stereotypical leadership style and when the evaluators were men. On the contrary, male leaders were not evaluated less favorably than females when they adopted a femalestereotypical leadership style, and female evaluators-in contrast to the males-did not favor female leaders over male leaders. Moreover, in the meta-analysis of gender and effectiveness of leaders, the results showed than male leaders were more effective than females in stereotypical male activities (those that require "task" skills: directing and controlling others), whereas female leaders were more effective than male leaders in stereotypical female activities (those that require "interpersonal" skills: cooperating and getting on well with others). Likewise, when there were a higher number of men among the evaluators, the male leaders obtained better evaluations of effectiveness than the females. However, female evaluators did not favor one sex over the other in their evaluations of effectiveness.

To sum up, the above results show that female leaders are at a disadvantage with regard to males when they adopt male-stereotypical styles and when the evaluators (their subordinates) are men. Therefore, differences in leadership 
between men and women are not so much due to the fact that they act differently but to differential reactions to the behavior of both sexes. Taking these and other results as a starting point, Eagly and Karau (2002) formulated the role congruity theory of prejudice toward female leaders (see Morales \& Cuadrado, 2004, for an analysis in Spanish of the theory). The central theme of the theory is that the perceived incongruity between the female stereotype and leadership roles is responsible for the existence of two kinds of prejudice towards female leaders and potential leaders, which results in a poorer appraisal of women's leadership behavior in comparison to that of men. The first kind of prejudice, proceeding from the descriptive component of the gender stereotypes-beliefs about men's and women's characteristics - is due to the mismatch between leadership roles and typically female characteristics. The second, derived from the prescriptive gender stereotypes-beliefs about the desirable characteristics of the members of each sex-is due to the fact that stereotypically male behavior is perceived as less desirable in women than in men. Thus, according to Eagly and Karau, female leaders or potential leaders receive fewer favorable evaluations than their males counterparts when they adopt male-stereotypical leadership styles-for example, autocratic and task-oriented styles-(see also Eagly et al., 2003, pp. 571-573).

It is noteworthy that men's and women's leadership behaviors are represented in the literature in a fairly isolated manner to facilitate their exposition, but in practice, there is more overlap. Thus, for example, a leader can, at the same time, be democratic, relationship-oriented, and task-oriented (see Cuadrado, 2001). However, the studies carried out to investigate the effects of leadership styles as a function of gender have not taken this aspect into account, but instead they have been limited to studying leadership differences between men and women separately (see Cuadrado, 2003). In fact, the meta-analysis of Eagly and Johnson (1990) on gender differences in leadership styles (162 studies that produce 370 comparisons) showed the extension of the works on this issue till the present; however, the studies included focus on the gender differences only in one kind of style: relationship-oriented/task-oriented, relationshiporiented and task-oriented, and autocratic versus democratic. Likewise, gender differences have not been investigated equally in all the styles or with the same methodology, so that autocratic versus democratic style is the least studied ( $n=28$ from 370 comparisons), and the experimental studies are the least numerous $(n=81$ out of a total of 370 comparisons). In general, women use the democratic style to a greater extent than men, and men use the autocratic style more frequently than women (see Cuadrado \& Navas, 2000 , for a more detailed analysis in Spanish of the results and implications of this and other meta-analyses of leadership and gender). Recently, a meta-analysis of the studies-all correlational—on gender differences and the transformational and transactional styles has been published (Eagly et al.,
2003). The general results show that women, in comparison to men, are more transformational and they are more committed to behaviors involving contingent reward (a component of transactional leadership). In contrast, male leaders display behaviors that represent passive leadership styles (direction by exception and laissez-faire) more frequently than do females.

Many studies have been carried out on the congruity between the typification of a gender role or activity and the sex of the person who performs it, synthesized in the metaanalysis of Davison and Burke (2000). Their results confirmed, in line with the role congruity theory of prejudice toward female leaders (Eagly \& Karau, 2002), that men and women were evaluated less favorably when they were selected to perform tasks that were incongruent with their gender. Given that leadership roles are male sex-typed, women are evaluated less favorably than men in these roles. Subsequent works that focused on the analysis of this aspect of the theory (García-Retamero \& López-Zafra, 2006) have experimentally confirmed that women are less likely than men to be promoted to a leadership positions, especially in settings that are incongruent with their gender role. Along the same line, Ritter and Yoder (2004) investigated experimentally the effect of the leader's (male or female) dominance, the type of task (male, female, or neutral), and the gender (same-sex or mixed dyads) on the emergence of leadership. Their results confirmed that, although women possess the agentic quality of dominance that is consistent with the leader's role, incongruity between masculinized task demands and gender stereotypes prevent women from emerging as leaders. On the other hand, the findings of the correlational study of Davis (2004) disprove Eagly and Karau's assumption that women leaders are evaluated as less effective than men in masculine work settings.

Other works have explicitly evaluated the congruity between context and leadership styles. For example, Gardiner and Tiggeman (1999) investigated the adoption of taskoriented and relationship-oriented leadership styles in organizations numerically dominated either by men or by women. Their results showed that, in organizations numerically dominated by men, the women adopted a malestereotypical leadership style and inhibit behaviors that are typical of "interpersonally-oriented" styles because of the negative consequences involved. Subsequently, van Engen, van der Leeden, and Willemsen (2001) investigated the influence of gender typification of jobs on leadership styles adopted by men and women. However, their results showed that there was no relation between the investigated leadership styles (task/relationship) and whether the context was masculine or feminine. In Spain, Cuadrado, Navas, and Molero (2004) studied the congruity between the leader's sex, gender typification of the organization, and leadership style. The results revealed that, according to their subordinates, women displayed "feminine" leadership behaviors to a greater extent in organizations "numerically 
dominated by women" and dedicated to "typically feminine" activities than in the opposite case (male leaders, in organizations "numerically dominated by men" and dedicated to "typically masculine" activities). Recently, Dulewicz and Higgs (2005) investigated leadership style in relation to the leaders' sector, gender, function, nationality, and personality traits. The results revealed that the leadership styles were independent of these variables.

Lastly, congruity between leadership style and the leader's sex has been investigated, but separately, to be precise, either with the autocratic versus democratic styles (see Luthar, 1996), or with task-oriented and relationshiporiented styles (see Rojhan \& Willemsen, 1994). In the first study, in contrast to the theory defended by Eagly and Karau (2002), it was experimentally shown that female leaders who adopted an autocratic style were evaluated more positively than male leaders who used this style. In the second study, the congruity between leadership style and the leader's sex did not produce effects in men's and women's general evaluations of leadership. It was merely found that male evaluators devalued men and women who used styles that were incongruent with their gender (women who adopted the task-oriented style and men who adopted the relationship-oriented style) and only in measures of efficacy (not in measures of leader's likeability). For the female evaluators, the evaluation did not vary as a function of the leader's sex and the style they adopted.

As can be seen, there are many works related to the goal of this article, but most of them do not address the issue directly. Some studies investigate the differences between men and women in leadership styles; others focus on the congruity between work setting-typically masculine or feminine-and sex of the occupants (independently of the leadership styles). In other works, the congruity between gender typification of the context and leadership styles was studied. In all these investigations, correlational or experimental designs were used, and the results obtained do not always point in the same direction.

Our goal is to verify experimentally one of the assumptions of the role congruity theory of prejudice toward female leaders (Eagly \& Karau, 2002): Women who occupy leadership roles are evaluated more unfavorably than men when they adopt stereotypically masculine styles. We shall also verify whether there are gender biases against women compared to men in the leadership evaluations they receive.

For this purpose, and in contrast to previous investigations, this study simultaneously includes the leadership styles most frequently studied from the psychosocial perspective, which have a stereotypically masculine or feminine nature, according to the literature. In other words, this study is not based on the differences between men and women, but on the styles related to the masculine or feminine dimension of gender stereotypes. Specifically, we study experimentally the effects of congruity between leadership styles (masculine-autocratic and task- oriented-and feminine-democratic, relationship-oriented, and individualized consideration) and the leader's sex, choosing a neutral context with regard to gender and maintaining the context constant. From all the above considerations, we formulate the following hypotheses:

Hypothesis 1: Female leaders will receive less favorable evaluations than male leaders when they adopt stereotypically masculine leadership styles (autocratic and task-oriented).

Hypothesis 2: Male leaders will not receive less favorable evaluations than female leaders when they adopt stereotypically feminine leadership behaviors (democratic, relationship-oriented, individualized consideration).

Hypothesis 3: Female leaders will receive worse evaluations from male evaluators than from female evaluators.

Hypothesis 4: Male leaders will receive similar evaluations from male and from female evaluators.

\section{Method}

\section{Participants}

The sample was made up of 136 psychology students from the Universidad Nacional de Educación a Distancia (National Open University of Spain), from the entire Spanish territory, of whom 53\% were women (mean age 27 years, $S D=6.6$ ) and the remaining $47 \%$ were men (mean age 29 years, $S D=6.8$ ). The participants were assigned randomly to each experimental condition (34 in each group), confirming group homogeneity with regard to sex. The only information provided about the investigation was that it was a study of decision making. Participants were in an introductory course of the $2^{\text {nd }}$ year of Social Psychology and were not familiar with the contents addressed in the study. Task duration was approximately 20 minutes. The participants received credit for their participation.

\section{Measures, Experimental Design, and Procedure}

Investigations on the effects of gender stereotypes on evaluations of leader usually use narrations that describe the leaders' behaviors, varying the leader's sex and keeping the remaining characteristics constant (Rojahn \& Willemsen, 1994). All such studies in which men's and women's behavior is kept constant, only varying the leader's sex, are variants of Goldberg's (1968) paradigm, the most frequently used to verify whether women are at a disadvantage with regard to men of the same characteristics. The most frequently employed procedure has been to present a case in which one half of the participants evaluate the leader with a woman's name and the other half evaluates the leader with a man's name (Eagly \& Karau, 2002, p. 582). Our 
work falls within the framework of this paradigm and, in addition to this variable, we also manipulated leadership style.

We elaborated a narrative in which we manipulated the leader's sex (male vs. female) and leadership style (malestereotypical, or autocratic and task-oriented vs. femalestereotypical: democratic, relationship-oriented, and individualized consideration). This narrative was especially written for this investigation. In it, participants are urged to imagine that they are part of an emergency service in a public health hospital. We chose this context because it is neutral regarding gender, in the sense that it is not typed as either masculine or feminine. Gender typification of an activity or context is based, on the one hand, on the numerical representation of each sex in the various occupations and, on the other, by the fact that either men or women are considered more suitable to perform activities that require stereotypically masculine or feminine characteristics, respectively (Davison \& Burke, 2000). Taking these observations into account, gender stereotypes are not easily activated in the setting of an emergency service of a public hospital (as could occur in an automobile factory or a beauty center). In fact, the context selected is not gendertyped in the meta-analyses of Eagly and Johnson (1990), Davison and Burke, or in the study by Cuadrado et al. (2004) carried out in Spain. On the other hand, this context is occupied both by doctors - a stereotypically masculine profession-and by nurses - a stereotypically feminine profession. This statement is based empirically on the percentages of men and women dedicated to these professions. In medicine, the presence of women has currently increased a great deal compared to the past, when it was considered a stereotypically masculine activity. Despite this, the percentage of female medical doctors is still lower than that of males (it was $37.82 \%$ in 2000 , and $42.10 \%$ in 2005). In contrast, nursing was and still is being performed, for the most part, by women-around $94 \%$ of women from 2000 to 2005 (Instituto de la Mujer [Women's Institute], 2006).

Participants were asked to evaluate a supervisor (male or female, depending on the experimental condition) of the service, who was occupying that positions for a trial period. In the narrative, after reading the description of the supervisor's behavior, they were asked to collaborate in the evaluation process by means of an anonymous questionnaire in order to facilitate making decisions about the candidates.

Four different versions of the same narrative were written, varying the leader's sex (male vs. female) and their leadership style (stereotypically masculine vs. stereotypically feminine). The narrative, which, except for the experimental manipulation of the variables, is similar in the four versions, describes the supervisor's behavior. The female leader's name was Lucía and the male leader's name was Carlos.

Autocratic and democratic leadership styles were operationalized in the versions from definitions of classic
(Lewin, 1939/1964; White \& Lippitt, 1960) and contemporary literature (Eagly \& Johnson, 1990; Luthar, 1996). In order to operationalize the task- and relationshiporiented styles, we used the study of Yukl (1999) as our starting point. Lastly, the operationalization of the transformational style of individualized consideration was based on the definition of this factor proposed by Bass and Avolio (1990), presented in the introduction. Several leadership experts reviewed the versions and their interrater agreement about the clear depiction of the leadership styles in the stories was confirmed. We reproduce below the part of the cases presented which refers to the operationalization of the variables in two of the experimental conditions (female leader with stereotypically feminine style and male leader with stereotypically masculine style):

\begin{abstract}
"Lucía called for a first meeting in which she presented all the information she had about the problem of user satisfaction. At this meeting, she encouraged the team members to express their opinions, to contribute their ideas, and to suggest possible actions to solve the problem. She appreciated and always took all the team members' suggestions into account. At this time, there were several internal arguments among various members of team, which Lucía tried to prevent. She offered encouragement and support when the situation became particularly difficult. Lucía allowed each team member to work with whomever they pleased, favoring the relations among the entire team. Lucía treated all the team members individually and made them feel that their contribution to the improvement of the service quality was important."

"Carlos called for a first meeting in which he presented all the information he had about the problem of user satisfaction. At this meeting, he informed the team about the activities he had decided to carry out to solve the problem. Carlos explained at the beginning the new tasks the team would have to carry out and indicated how to perform them. He planned in detail how to achieve each task, and the responsibilities of each team member and the specific results he expected. He explained how to organize and coordinate the work activities to avoid delays, duplication of efforts, and wasting resources. Carlos treated all the team members like the components of a group and he made them feel that the contribution of the group in general to the improvement of the service quality was important."
\end{abstract}

Therefore, the experimental manipulation of the leader's sex (male vs. female) and leadership style (stereotypically masculine vs. stereotypically feminine) led to a $2 \times 2$ (Sex $\times$ Style) factor design with 34 subjects in each experimental condition. Neither leadership style nor leader's sex were measured as intrasubject variables, because the participants could easily find out the goals of the investigation and, thus, bias the results.

After reading the narrative, the participants had to complete various measures: 
1. A list of 14 adjectives ( 7 positive and 7 negative), selected from the study of Rudman and Kilianski (2000). Participants rated the degree to which they thought these adjectives were applicable to the supervisor, using a 7-point Likert-type frequency category scale, ranging from 1 (never) to 7 (always). The positive adjectives were: competent, intelligent, loyal, honest, clever, responsible, and optimistic. The negative adjectives were: careless, forgetful, discouraging, harmful for the team, bossy, snobbish, and dishonest. These adjectives were used to determine the direction of the evaluation and the image the participants had formed of the leader.

2. Supervisor's leadership capacity. A measure of 4 items selected from the study of Luthar (1996) and of Rojhan and Willemsen (1994), with a 7-point Likerttype scale, ranging from 1 (totally negative/totally disagree) to 7 (totally positive/totally agree). The items presented were: How would you evaluate X's general leadership capacity? $\mathrm{X}$ is a competent supervisor. How would you evaluate X's capacities and aptitudes as a supervisor? How would you evaluate $\mathrm{X}$ as a leader or supervisor?

3. Leadership effectiveness of the supervisor. A measure of 5 items selected from the study of Luthar (1996) and of Rojhan and Willemsen (1994), with a 7-point Likert-type scale ranging from 1 (totally negative/totally disagree) to 7 (totally positive/totally agree). The items presented were: How would you evaluate X's general achievement as a supervisor? X is an effective manager. $\mathrm{X}$ knows how to manage people effectively. $\mathrm{X}$ has sufficient capacity to be considered a successful leader. $\mathrm{X}$ does not perform his/her work as supervisor well enough.

Finally, we included seven manipulation-check items to verify that the experimental manipulation had had some effect.

A pilot study was carried out to test the functioning of all the aspects of the investigation, in particular, the narratives and dependent variables. In this pilot study, 40 psychology students from the Universidad de Almería (75\% women and $25 \%$ men) participated, mean age 22.1 years $(S D=9.6)$. To evaluate the different versions of the narrative, a 7-point Likert scale, ranging from 1 (completely disagree) to 7 (completely agree) was used where participants rated the credibility, concision, clarity, and truth of the information presented, both in the general narrative and in the different versions. In all the items, the median of the scores corresponded to the value 5 (agree a lot) or 6 (agree very mисh), so, in general, the participants considered that the information presented was credible, concise, clear, and, true. With regard to the psychometric quality of the measures of the dependent variable, reliability was calculated with the alpha coefficient, finding values of .86 for the items of leadership capacity, .89 for the items of efficacy in leadership performance, and .89 for the list of adjectives.

\section{Data Analysis}

After having confirmed that the pertinent assumptions were met to perform parametric tests on the definite sample, we analyzed the mean differences (Student's $t$ test) between the leadership styles in the seven manipulationcheck items to determine whether the experimental manipulation of the independent variable leadership style had had effect. Likewise, we analyzed the reliability of the measures used to estimate leadership with the alpha coefficient. To verify the research hypotheses, we conducted two ANOVAs: a $2 \times 2$ (Leader's sex $\times$ Leadership style) ANOVA for Hypotheses 1 and 2, and a $2 \times 2$ (Leader's sex $\times$ Evaluator's sex) ANOVA for Hypotheses 3 and 4 . All the analyses were performed with the statistical package SPSS 12.0.

\section{Results}

\section{Manipulation Check}

We compared the responses of the participants assigned to the "stereotypically masculine" condition with those assigned to the "stereotypically feminine" condition in the seven manipulation-check items inserted in the questionnaire. The analyses confirmed the validity of the experimental manipulation (see Table 1). For example, in the first control item, " $\mathrm{X}$ has a style that is basically oriented to the team members," the mean of the participants who read the narrative about a leader with a stereotypically masculine style was significantly lower than the mean of the participants who read the narrative about a stereotypically feminine style.

All the mean differences were statistically significant at $p<.01$, except for those of the item "X's style can be considered stereotypically feminine," which was statistically significant at $p<.05$.

\section{Reliability of the Dependent Variables}

We calculated the alpha coefficient, finding $\alpha=.85$ for the adjective list, $\alpha=.90$ for items of leadership capacity, and $\alpha=.91$ for items of leadership efficacy. The correlation between the total score in leadership capacity and leadership efficacy was .88 , which provides evidence of the validity of both scales, given the proximity of the terms.

\section{Testing the Study Hypotheses}

As displayed in Table 2, the ANOVA revealed a significant main effect of the variable leadership style on the three dependent variables, $F(1,126)=70.34, F(1,126)$ $=45.15$, and $F(1,126)=29.10$, for the adjective list, leadership capacity, and leadership efficacy, respectively ( $\mathrm{p}$ 
Table 1

Mean Differences between the Leadership Styles in the Manipulation-Check Items

\begin{tabular}{|c|c|c|c|}
\hline Items & $\begin{array}{c}\text { Stereotypically } \\
\text { masculine style } \\
M\end{array}$ & $\begin{array}{c}\text { Stereotypically } \\
\text { feminine style } \\
M\end{array}$ & $t(134)$ \\
\hline $\begin{array}{l}\text { 1. X's style is basically oriented to members of the team } \\
\text { (relationship-oriented; SF) }\end{array}$ & 1.88 & 5.21 & $-13.86^{* *}$ \\
\hline 2. X's style can be considered stereotypically male & 4.38 & 3.38 & $3.59 * *$ \\
\hline $\begin{array}{l}\text { 3. X's style is basically oriented to achieving the task goals } \\
\text { (task-oriented; SM) }\end{array}$ & 6.18 & 4.16 & $7.61 * *$ \\
\hline $\begin{array}{l}\text { 4. } \mathrm{X} \text { does not allow the team to participate in the decision } \\
\text { making (autocratic; } \mathrm{SM} \text { ) }\end{array}$ & 5.85 & 1.9 & $13.47 * *$ \\
\hline 5. X's style can be considered stereotypically female & 2.93 & 3.57 & $2.61 *$ \\
\hline $\begin{array}{l}\text { 6. X promotes the team's participation in the decision } \\
\text { making (democratic; SF) }\end{array}$ & 1.78 & 5.76 & $-15.91 * *$ \\
\hline $\begin{array}{l}\text { 7. } \mathrm{X} \text { considers the team members individually } \\
\text { (individualized consideration; } \mathrm{SF} \text { ) }\end{array}$ & 1.88 & 5.72 & $-13.46 * *$ \\
\hline
\end{tabular}

Note. $\mathrm{SM}=$ stereotypically masculine; $\mathrm{SF}=$ stereotypically feminine; $\mathrm{X}=$ leader's name (Lucía or Carlos).

$* p<.05 . * * p<.01$.

Table 2

Means and Standard Deviations (in Brackets) and Effects of Leader's Sex, Leadership Style, and their Interaction on the Adjective List, Leadership Capacity, and Leadership Efficacy

\begin{tabular}{|c|c|c|c|c|c|c|c|c|c|c|c|}
\hline \multirow[b]{3}{*}{$\begin{array}{l}\text { Dependent } \\
\text { variables }\end{array}$} & \multirow{2}{*}{\multicolumn{3}{|c|}{ Leader's Sex }} & \multirow{2}{*}{\multicolumn{3}{|c|}{ Leadership Style }} & \multicolumn{5}{|c|}{ Sex $\times$ Style Interaction } \\
\hline & & & & & & & \multicolumn{2}{|c|}{ Hypothesis 1} & \multicolumn{3}{|c|}{ Hypothesis 2} \\
\hline & $\begin{array}{c}\text { Male } \\
M(S D)\end{array}$ & $\begin{array}{l}\text { Female } \\
M(S D)\end{array}$ & $F(1,126)$ & $\begin{array}{c}\mathrm{SM} \\
M(S D)\end{array}$ & $\begin{array}{c}\mathrm{SF} \\
M(S D)\end{array}$ & $F(1,126)$ & $\begin{array}{c}\text { Male SM } \\
M(S D)\end{array}$ & $\begin{array}{c}\text { Female SM } \\
\qquad M(S D)\end{array}$ & $\begin{array}{r}\text { Male SF } \\
M(S D)\end{array}$ & $\begin{array}{c}\text { Female } \mathrm{SF} \\
M(S D)\end{array}$ & $F(1,126)$ \\
\hline $\begin{array}{l}\text { Adjective } \\
\text { list }\end{array}$ & $4.92(.64)$ & $4.90(1.03)$ & 0.02 & $4.32(.73)$ & $5.51(.87)$ & $70.34 * *$ & $4.30(.64)$ & $4.34(.82)$ & $5.55(.84)$ & $5.47(.91)$ & 0.21 \\
\hline $\begin{array}{l}\text { Leadership } \\
\text { capacity }\end{array}$ & $4.76(1.52)$ & $4.73(1.39)$ & 0.02 & $4.00(1.26)$ & $5.48(1.24)$ & $45.15^{* *}$ & $3.83(1.39)$ & $4.17(1.13)$ & $5.63(1.11)$ & $5.36(1.36)$ & ) 1.25 \\
\hline $\begin{array}{l}\text { Leadership } \\
\text { efficacy }\end{array}$ & $4.87(1.46)$ & $4.74(1.32)$ & 0.34 & $4.21(1.36)$ & $5.41(1.15)$ & $29.10^{* *}$ & $4.18(1.56)$ & $4.21(1.14)$ & $5.52(1.01)$ & $5.33(1.29)$ & 0.22 \\
\hline
\end{tabular}

Note: $\mathrm{SM}=$ stereotypically masculine; $\mathrm{SF}=$ stereotypically feminine.

$* * p<.01$.

$<.01$ in all cases). However, as can be seen, no effect of the variable leader's sex or of the interaction of these variables was found.

Thus, the results show that, independently of their sex, when leaders adopt a stereotypically feminine leadership style, they obtain significantly more favorable evaluations on the adjective list, in the items of leadership capacity, and in the items that measure leadership efficacy (see Figure 1). Therefore, the results of the study reject the devaluation of women when they adopt a masculine leadership style, as this style received the least favorable evaluations in both sexes. Hence, we found no empirical evidence to support our first hypothesis.
However, the lack of differences in the evaluation received by male and female leaders who adopt stereotypically feminine styles supports our second hypotheses (see Table 2). Nevertheless, this result should be interpreted with caution, as it did not occur in combination with the first hypothesis. Men did not receive less favorable evaluations when they adopted stereotypically feminine leadership styles (confirmation of Hypothesis 2), but neither were the women devaluated when they managed in stereotypically masculine ways (rejection of Hypothesis 1). Therefore, neither sex was evaluated unfavorably when adopting gender incongruent styles (contrary to what could be expected for female leaders). 


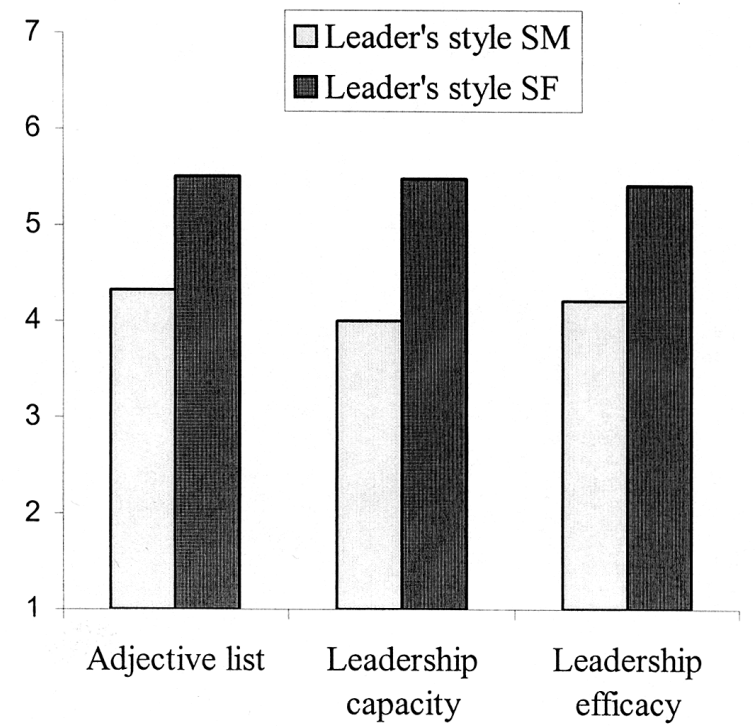

Figure 1. Effects of leadership style ( $\mathrm{SM}=$ stereotypically masculine; $\mathrm{SF}=$ stereotypically feminine) on the adjective list, leadership capacity, and leadership efficacy.

With regard to Hypotheses 3 and 4, the ANOVA revealed no main effects of either of the two independent variables or of their interaction. The mean evaluation of the leaders was practically identical in males and females on the adjective list, $F(1,124)=.001, p=.98$, in leadership capacity, $F(1,124)=.013, p=.91$, and in leadership efficacy, $F(1,124)=.170, p=.68$. Concerning the evaluator's sex, the evaluations made by men and women were also similar in the adjective list, $F(1,124)=.02, p=$ .88 , in leadership capacity, $F(1,124)=.003, p=.88$, and in efficacy, $F(1,124)=.007, p=.94$. The interaction of the independent variables (leader's sex and evaluator's sex) did not yield statistically significant results in the evaluation of leadership in any of the three variables under consideration: $F(1,124)=.001, p=.98 ; F(1,124)=.166, p=.69$, and $F(1,124)=.117, p=.73$, for the adjective list, leadership capacity, and leadership efficacy, respectively.

\section{Discussion}

As mentioned, the main goal of our work was to verify whether women are evaluated less favorably than men when they manage in a stereotypically masculine way. The results of our study reject this devaluation and show that this style is actually evaluated less favorably in both sexes. Thus, the main finding is that leaders, independently of their sex, receive significantly better evaluations in the three measures included (adjective list, leadership capacity, and performance efficacy) when they adopt stereotypically feminine leadership styles (versus stereotypically masculine styles). These results emerge regardless of whether the evaluators are men or women.
These results have some important implications for the literature on leadership and gender. Thus, it is not confirmed that women in leadership positions who adopt stereotypically masculine ways are less favorably evaluated than men (Eagly $\&$ Karau, 2002). Like in other studies, the assumption on which the role congruity theory of prejudice toward female leaders is based is not confirmed (e.g., Davis, 2004; Dulewicz \& Higgs, 2005; van Engen et al., 2001; Rojhan \& Willemsen, 1994). What can be the explanation of these results?

On the one hand, it is fairly likely that the context used in this study (a hospital, which is not sex-typed) may have influenced the results. These results suggest that, to the extent to which activities and contexts cease to be stereotyped as masculine or feminine, the evaluation of female leaders will improve. On the other hand, the data on which Eagly and Karau (2002) base this part of their theory proceed from the meta-analysis of gender and evaluation of leaders (Eagly et al., 1992). The changes that have occurred since performing the studies that made up the meta-analysis (the average year of publication was 1980) till the present are, in our opinion, another key factor. As noted by Eagly and Carli (2003b), "the increase in female leaders has been accompanied by changes in theories and practices of leadership" (p. 809). Thus, in psychosocial literature, the existence of what is called the "female leadership advantage" is debated: stereotypically feminine leadership styles are an advantage for women because they are in consonance with current organizational demands.

However, there are some studies (see, for example, Cuadrado, 2004) that show that female leaders describe themselves using instrumental traits and they assign more importance to individualist values (both related to the masculine dimension of gender stereotypes) to a greater extent than do women who do not occupy leadership positions. In other words, women who occupy leadership positions continue to emulate masculine behavior, traditionally associated with professional success in leadership posts.

Fortunately, in the present study, as predicted by the role congruity theory of prejudice toward female leaders (Eagly \& Karau, 2002), men are not evaluated less favorably than women if they transgress the prescriptions associated with their gender, namely, if they use stereotypically feminine styles. Thus, Eagly and Karau acknowledge that over the last years, there has been little change in the content of gender stereotypes, but there has been a greater change, tending toward androgyny, in the leadership profile demanded by organizations (see Barberá et al., 2005). It is fairly likely, therefore, that one of the consequences of this evolution is that men become aware that they should let go of the traditional style of direction and control and manage in a more feminine or androgynous way because of the positive consequences this may have in their performance as leaders. This, in turn, might allow women to adopt 
leadership styles more congruent with their stereotype, as well as to cease receiving unfavorable evaluations when they add agentic (masculine) behaviors to their communal (feminine) repertory. The results of this study indicate that this is possible. Future investigations should study the results obtained when using different participants and settings.

In short, our study reveals that female leaders do not receive less favorable evaluations than males when they adopt stereotypically masculine styles (i.e., autocratic), nor is there a biased tendency in men to favor leaders of their own sex, as Eagly et al. (Eagly, Makhijani, et al., 1992; Eagly, Karau, et al., 1995) found in their meta-analyses. In view of these results, one could wonder why women are not sufficiently represented in leadership roles. In other words, the scarcity of women in these positions is difficult to understand if, as revealed by the results of this study and other works (see Barberá \& Ramos, 2004), the adoption of stereotypically feminine styles is more highly valued than masculine styles and more congruent with current organizational demands.

Firstly, the existence of a persistent stereotype that associates managerial activities with stereotypically male qualities should be taken into account. Through diverse studies in different countries, this phenomenon, called "think manager-think male" in the literature, is global and is especially sustained by men (see Schein, 2001). Therefore, the traits, values, or behaviors linked to masculinity are considered necessary to achieve success in managerial positions. As a result, some women who occupy leadership positions continue to emulate male behavior traditionally associated with professional success in leadership positions (see Cuadrado, 2004). However, when doing this, women contravene desirable feminine behavior, namely, they transgress the prescriptions associated with their gender and are evaluated negatively, as was developed extensively in the theory formulated by Eagly and Karau (2002). Because of this, there is both a process of self-exclusion, known as the "cement ceiling"-self-imposed by personal choices, such as rejecting promotion (Chinchilla \& León, 2004)as well as the existence of greater difficulty to achieve these roles in comparison to men.

However, as aptly noted by Eagly (2003), the growing presence of women in these positions, together with a higher evaluation of stereotypically feminine qualities-which at the same time are appropriate to the current needs of the diverse settings (see the analysis of Barberá et al., 2005) are important factors that will favor female presence in leadership positions. This study confirms these statements. The changes-though slow-in the content of gender stereotypes (see Barberá \& Ramos, 2004) and the decrease of incongruity between leadership roles and the feminine role will allow organizations to be more receptive to female leaders. Of course, this optimistic viewpoint should be interpreted with realism. In fact, the statistics still show that women have not yet advanced as much as would be fair and desirable. There is still discriminatory treatment toward female leaders or toward women who attempt to perform these roles, but, from our viewpoint, some conditions must be met for this to occur. For example, it is more likely to occur in people who display strong gender stereotypes, and when women try to gain access to positions of power and prestige in jobs that are incongruent with their gender. We hope these events will become more anecdotic and the results obtained in this experiment will become a reflection of some social advances on the way toward true equality.

Despite these favorable results, this investigation has some limitations that are habitual in experimental studies carried out with university students. Nevertheless, as indicated by Eagly and Karau (2002, p. 587), the samples of most experiments on leadership styles under Goldberg's paradigm are made up of university students. Another limitation refers to external validity. However, according to Dipboye and Flanagan (1979), limited external validity is applicable both to experimental studies and to field studies as, in both cases, the sample, situations, and behaviors are selected. In this sense, our results would be more generalizable if similar experiments were carried out with different kinds of samples and in different settings. Likewise, it would be interesting to confirm that the results concerning the better evaluation of the feminine leadership style are replicated using other experimental designs.

While aware of the limitations, the main implication of these results for the access of women to leadership positions is that organizations should take into account the contributions and the value of feminine styles, instead of blocking women's access to traditionally masculinized settings. Likewise, they should consider the importance of the feminine styles when training managerial skills and styles. It is very likely that these aspects, together with the growing access of women to leadership positions-which will gradually modify the content of gender stereotypeswill prevent the devaluation of female leaders and allow egalitarian access of men and women to positions of responsibility. Not only women, but organizations and society in general can achieve important benefits.

\section{References}

Ayestarán, S. (2003). ¿Dirigen las mujeres igual que los hombres? Revista de Psicología Social, 18, 315-319.

Barberá, E., Candela, C., López, M., Ramos, A., Sarrió, M., Albertos, P., Benítez, I.J., Díez, J.L. y Lacort, J.A. (2005). Género y diversidad en un entorno de cambio. Valencia: Universidad Politécnica de Valencia.

Barberá, E., \& Ramos, A. (2004). Liderazgo y discriminación de género. Revista de Psicología General y Aplicada, 57, 147160. Monographic issue: La psicología y el acceso de la mujer a la función directiva. (Coords.: J.F. Morales \& I. Cuadrado). 
Bass, B.M., \& Avolio, B.J. (1990). Transformational leadership development: Manual for the Multifactor Leadership Questionnaire. Palo Alto, CA: Consulting Psychologists Press.

Cann, A., \& Siegfried, W.D. (1990). Gender stereotypes and dimensions of effective leader behaviour. Sex Roles, 23, 413-419.

Chinchilla, N., \& León, C. (2004). La ambición femenina. Cómo re-conciliar trabajo y familia. Madrid: Aguilar.

Cuadrado, I. (2001). Cuestiones teóricas y datos preliminares sobre tres estilos de liderazgo. Revista de Psicología Social, 16, 131155.

Cuadrado, I. (2003). ¿Emplean hombres y mujeres diferentes estilos de liderazgo? Análisis de la influencia de los estilos de liderazgo en el acceso a los puestos de dirección. Revista de Psicología Social, 18, 283-307.

Cuadrado, I. (2004). Valores y rasgos estereotípicos de género de mujeres líderes. Psicothema, 16, 279-284.

Cuadrado, I., \& Molero, F. (2002). Liderazgo transformacional y género: autoevaluaciones de directivos y directivas españoles. Revista de Psicología del Trabajo y de las Organizaciones, 18, 39-55.

Cuadrado, I., \& Navas, M. (2000). La técnica del meta-análisis aplicada al estudio del liderazgo y el género: resultados e implicaciones. Revista de Psicología General y Aplicada, 53, 303-317.

Cuadrado, I., Navas, M., \& Molero, F. (2004). El acceso de las mujeres a puestos directivos: género, contexto organizacional y estilos de liderazgo. Revista de Psicología General y Aplicada, 57, 181-192. Monographic issue: La psicología y el acceso de la mujer a la función directiva. (Coords.: J.F. Morales \& I. Cuadrado).

Cuadrado, I., Navas, M., \& Molero, F. (2006). Mujeres y liderazgo: claves psicosociales del techo de cristal. Madrid: Sanz y Torres.

Davis, C.A. (2004). Gender stereotypes and 360-degree leadership feedback ratings: An application of role congruity theory. Doctoral dissertation. University of Michigan. University Microfilms International.

Davison, H.K., \& Burke, M.J. (2000). Sex discrimination in simulated employment contexts: A meta-analytic investigation. Journal of Vocational Behavior, 56, 225-248.

Dipboye, R.L., \& Flanagan, M.F. (1979). Research settings in industrial and organizational psychology: Are findings in the field more generalizable than in the laboratory? American Psychologist, 34, 141-150.

Dulewicz, V., \& Higgs, M. (2005). Assessing leadership styles and organizational context. Journal of Managerial Psychology, 20, 105-123.

Eagly, A.H. (2003). The rise of female leaders. Zeitschrift für Sozialpsychologie, 34, 123-132.

Eagly, A.H., \& Carli, L.L. (2003a). Finding gender advantage and disadvantage: Systematic research integration is the solution. Leadership Quarterly, 14, 851-859.

Eagly, A.H., \& Carli, L.L. (2003b). The female leadership advantage: An evaluation of the evidence. Leadership Quarterly, 14, 807-834.

Eagly, A.H., \& Johannesen-Schmidt, M.C. (2001). The leadership styles of women and men. Journal of Social Issues, 57, 781-797.
Eagly, A.H., Johannesen-Schmidt, M.C., \& van Engen, M. (2003). Transformational, transactional and laissez-faire leadership styles: A meta-analysis comparing women and men. Psychological Bulletin, 129, 569-591.

Eagly, A.H., \& Johnson, B.T. (1990). Gender and leadership style: A meta-analysis. Psychological Bulletin, 108, 233-256.

Eagly, A.H., \& Karau, S.J. (2002). Role congruity theory of prejudice toward female leaders. Psychological Review, 109, 573-598.

Eagly, A.H., Karau, S.J., \& Makhijani, M.G. (1995). Gender and the effectiveness of leaders: A meta-analysis. Psychological Bulletin, 117, 125-145.

Eagly, A.H., Makhijani, M.G., \& Klonsky, B.G. (1992). Gender and the evaluation of leaders: A meta-analysis. Psychological Bulletin, 111, 3-22.

García-Retamero, R., \& López-Zafra, E. (2006). Congruencia de rol de género y liderazgo: el papel de las atribuciones causales sobre el éxito y el fracaso. Revista Latinoamericana de Psicología, 38, 245-257.

Gardiner, M., \& Tiggemann, M. (1999). Gender differences in leadership style, job stress and mental health in male- and female- dominated industries. Journal of Occupational and Organizational Psychology, 72, 301-315.

Goldberg, P. (1968). Are women prejudiced against women? Transaction, 5, 316-322.

Helgesen, S. (1990). The female advantage: Women's' ways of leadership. New York: Doubleday Currency.

Instituto de la Mujer (2006). Las mujeres en cifras. Data obtained on October 8 at http://www.mtas.es/mujer/mujeres/cifras/tablas/ W582.XLS

Lewin, K. (1939/1964). Experiments in social space. In D. Cartwright (Ed.), Field theory in social science: Selected theoretical papers by Kurt Lewin (pp. 71-83). New York: Harper Torchbooks.

Luthar, H.K. (1996). Gender differences in evaluation of performance and leadership ability: Autocratic vs. democratic managers. Sex Roles, 35, 337-361.

Morales, J.F., \& Cuadrado, I. (2004). Introducción: Teoría de congruencia de rol del prejuicio hacia líderes femeninos. Revista de Psicología General y Aplicada, 57, 135-146. Monographic issue: La psicología y el acceso de la mujer a la función directiva (Coords.: J.F. Morales \& I. Cuadrado).

Moya, M. (2003). Sobre la existencia y el origen de las diferencias en el liderazgo entre hombres y mujeres. Revista de Psicología Social, 18, 321-325.

Munduate, L. (2003). Género y liderazgo: diferencias entre hombres y mujeres en el acceso a los puestos directivos. Revista de Psicología Social, 18, 309-314.

Ritter, B.A., \& Yoder, J.D. (2004). Gender differences in leader emergence persist even for dominant women: An updated confirmation of role congruity theory. Psychology of Women Quarterly, 28, 187-193.

Rojahn, K., \& Willemsen, T.M. (1994). The evaluation of effectiveness and likeability of gender-role congruent and gender-role incongruent leaders. Sex Roles, 30, 109-119. 
Rudman, L.A., \& Kilianski, S.E. (2000). Implicit and explicit attitudes toward female authority. Personality and Social Psychology Bulletin, 26, 1315-1328.

Schein, V.E. (2001). A global look at psychological barriers to women's progress in management. Journal of Social Issues, 57, 675-688.

van Engen, M. L., van der Leeden, R., \& Willemsen, T.M. (2001). Gender, context and leadership styles: A field study. Journal of Occupational and Organizational Psychology, 74, 581598.

van Engen, M.L., \& Willemsen, T.M. (2004). Sex and leadership styles: A meta-analysis of research published in the 1990s. Psychological Reports, 94, 3-18.
Vecchio, R.P. (2002). Leadership and gender advantage. Leadership Quarterly, 13, 643-671.

Vecchio, R.P. (2003). In search of gender advantage. Leadership Quarterly, 14, 835-850.

White, R.K., \& Lippitt, R. (1960). Autocracy and democracy: An experimental inquiry. New York: Harper.

Yukl, G. (1999). An evaluative essay on current conceptions of effective leadership. European Journal of Work and Organizational Psychology, 8, 33-48.

Received June, 9, 2006 Revision received April, 9, 2007 Accepted April, 13, 2007 